\title{
Democratic Transitions
}

\section{Citation}

Epstein, David L., Robert Bates, Jack Goldstone, Ida Kristensen, and Sharyn 0'Halloran. 2006. Democratic transitions. American Journal of Political Science 50(3): 551-569.

\section{Published Version}

http://dx.doi.org/10.1111/j.1540-5907.2006.00201.x

\section{Permanent link}

http://nrs.harvard.edu/urn-3:HUL.InstRepos:3322248

\section{Terms of Use}

This article was downloaded from Harvard University's DASH repository, and is made available under the terms and conditions applicable to Other Posted Material, as set forth at http:// nrs.harvard.edu/urn-3:HUL.InstRepos:dash.current.terms-of-use\#LAA

\section{Share Your Story}

The Harvard community has made this article openly available.

Please share how this access benefits you. Submit a story.

Accessibility 


\title{
Democratic Transitions
}

\author{
David L. Epstein, Robert Bates, Jack Goldstone, \\ Ida Kristensen, and Sharyn O'Halloran*
}

August 15, 2005

\begin{abstract}
Przeworski, Alvarez, Cheibub, and Limongi (2000) challenge the key hypothesis in modernization theory: political regimes do not transition to democracy as per capita incomes rise, they argue. Rather, democratic transitions occur randomly, but once there, countries with higher levels of GDP per capita remain democratic. We retest the modernization hypothesis using new data, new techniques, and a three-way rather than dichotomous classification of regimes. Contrary to Przeworski et. al. (2000) we find that the modernization hypothesis stands up well. We also find that partial democracies emerge as among the most important and least understood regime types.
\end{abstract}

${ }^{*}$ Epstein, Kristensen, and O'Halloran: Department of Political Science, Columbia University; Bates: Department of Government, Harvard University; Goldstone: School of Public Policy, George Mason University. 


\section{Introduction}

The study of democratization is one of the most venerable literatures in comparative politics. It is also one of the most vigorous, as controversies over theory and method interact with empirical research in debates over the origins and determinants of democratic forms of government. In recent years, however, an uncharacteristic lull seems to have descended on this vibrant field - a lull we attribute to the need to absorb the pivotal contribution of Przeworski, Alvarez, Cheibub, and Limongi (2000) (hereafter referenced PACL). Despite the challenges posed by Boix (2002) and Boix and Stokes (2003), rather than igniting debate, as would be right and proper, PACL appear instead to have quenched it.

Among the most notable of PACL's findings is that modernization-specifically, an increase in per capita GDP - is not a causal factor in the process of democratization. Rather, they argue, the positive association between income and democracy results from the reduced likelihood of more modern countries sliding back, as it were, into undemocratic forms of government once having (randomly) become democratic. This finding is now treated as received wisdom.

We challenge that finding. The grounds for our dissent are both methodological and substantive. PACL employ a dichotomous classification of political systems, in which governments are either democratic or authoritarian, with rather stringent requirements for being included in the former category. All countries failing to meet the necessary conditions for being a full democracy are then deemed autocratic.

This approach, however, ignores the possibility of an intermediate category, "partial democracies," which possess some, but not all, of the properties that characterize full democracies. Not only are such regimes becoming more numerous, there is also growing evidence that they behave differently from either full democracies or full autocracies. Mansfield and Snyder (1995), for instance, show that partial democracies are more likely to become involved in armed conflicts with other countries. Bacher (1998) argues that countries in the similar Freedom House category of "partially free" regimes are most likely to enact policies that harm the environment. Goldstone, et. al. (2000) demonstrate that partial democracies are more prone to political instability, revolutions, and ethnic wars. And Zakaria (2003), terming such regimes "illiberal democracies," warns that they can be just as oppressive and contemptuous of human rights as any dictatorship.

In this article, we first review and critique the work of PACL. We indicate that they mistakenly interpret their own estimates in a manner that predisposes them to reject the modernization hypothesis. Shifting from their dichotomous to our trichotomous measure of democracy, we recreate their result; employing Markov estimation, as do they, we then demonstrate that our trichotomous measure is to be preferred.

What we learn from these efforts is that higher per capita incomes increase the likelihood of a movement away from autocracy as well as decrease the likelihood of a movement away from democracy. That is, we find reason (contra PACL) to support the modernization hypothesis. In our view, democracy is a process, not an end state. And as is often the case, the journey is more important than the destination.

We also learn that the frontier of this line of inquiry has shifted away from the study of autocracies and democracies and toward the study of partial democracies. As we show here, the behavior of these systems largely determines the level, rate, and properties of 
democratization. While thus influential, partial democracies, being highly heterogeneous, are poorly understood. The study of democratization, we therefore conclude, should place them at its focus.

The following section reviews the relevant literature on modernization theory. After reviewing the results of previous research, we summarize the data used in our analysis and our statistical techniques: tobit, Markov, and duration models. We then present our own findings. The last section concludes by emphasizing the significance of partial democracies.

\section{Modernization Theory}

Modernization theory was first developed by Daniel Lerner (1958), a behavioral scientist studying the role of the media in development (see also Deutsch 1961). Lerner designated as modern those societies whose people are literate, urban-dwelling, and better off, in the sense of commanding higher incomes. The later works of economists, such as Rostow (1960), Kuznets (1966) and Chenery and Taylor (1968), focused on economic modernization. In so doing, they emphasized the importance of structural change and associated the rise of per capita incomes with the decline of the agrarian economy and the rise of urban industry.

The classic statement of the relationship between modernization and politics originates from Lipset (1959), who first established the link between the level of per capita income and democracy in a global cross-section of nations. Lipset hypothesized that as societies develop economically, their citizens no longer tolerate repressive political regimes. The rise in per capita GDP, he argued, triggers a transition to democracy.

Pioneering the small-N research tradition in comparative historical sociology, Barrington Moore (1966) related democratization to the rise of the middle class and to the terms of its political incorporation, a result upheld by Rueschemeyer, Stephens, and Stephens (1992). More common is the use of large-N data sets, with important contributions from Cutright (1963), Dahl (1971), and Burkart and Lewis-Beck (1994), among others. Londregan and Poole (1996) perform an especially careful test of the relation between income and democracy and find a significant, albeit modest, effect.

Against this background, Przeworski and his co-authors advanced an important new argument. ${ }^{1}$ Reminding us that correlation does not necessarily imply causation, PACL note that countries may become democratic due to reasons unrelated to their level of economic development. Once prosperous, however, if democracies with higher levels of GDP per capita were to avoid slipping back into autocracy, then over time the relationship between GDP and democracy would emerge. It would do so even though economic growth does not cause democratization.

We agree with PACL that a true test of modernization theory should examine both the impact of GDP on democratization and its ability to promote the consolidation of established democracies. However, we take issue with their conclusion that economic development does not play a significant role in transitions away from autocracy. We dissent because we find their own work flawed and because a more refined measure of regime type generates evidence of the impact of GDP that their measure obscures.

\footnotetext{
${ }^{1}$ See Przeworski, Alvarez, Cheibub, and Limongi (1996), Przeworski and Limongi (1997), and especially Przeworski, Alvarez, Cheibub, and Limongi (2000).
} 
As mentioned, Boix and Stokes (2003) also challenge the PACL findings. Their criticism is somewhat muted, however, as they essentially agree with PACL that the impact of GDP on democratization in the postwar period is negligible, even though it may be statistically significant. They argue that it is the prewar period - from the late 19th century through the 1940's - in which the impact of GDP on democracy is most powerful. Although we agree with Boix and Stokes that the patterns of GDP and democratization are clear in the prewar period, we argue that the same patterns are important in the postwar era as well.

\section{The Work of PACL}

As we have observed, PACL (2000) employ a dichotomous regime classification. If (i) the chief executive is elected; (ii) the legislature is elected; (iii) there is more than one political party; and (iv) an incumbent regime has lost power, then the country is deemed democratic; otherwise, it is classified authoritarian. Using this definition, PACL claim that increases in per capita GDP do not influence transitions from autocracy to democracy; rather, they help countries that are already democratic remain so. They base their conclusions on Tables 2.12 and 2.17 from Chapter 2 of their book. The former, reproduced as the first two columns of Table 1, performs a Markov probit regression of regime type on lagged values of per capita $G D P$, its square, and year-to-year GDP growth:

$$
\begin{aligned}
P\left(D_{i t}\right)=\Phi\left\{\beta_{0}+\beta_{1} G D P+\beta_{2} G D P^{2}+\beta_{3} \text { Growth }+\right. & \\
& \left.\beta_{4} I_{D}+\beta_{5} I_{D} G D P+\beta_{6} I_{D} G D P^{2}+\beta_{7} I_{D} \text { Growth }\right\},
\end{aligned}
$$

where $P\left(D_{i t}\right)$ signifies the probability that country $i$ is a dictatorship in year $t, \Phi(\cdot)$ is the cumulative normal distribution, and $I_{D}$ is an indicator variable for dictatorship in the previous period. ${ }^{2}$ As indicated in the first two columns of Table 1, PACL report the coefficients on $G D P$ and $G D P^{2}$ in this regression as insignificant when predicting transitions both to and from democracy. PACL take this as evidence that the level of GDP per capita does not influence democratic transitions.

Note that when $I_{D}=1$ in Equation 1 , the coefficient on $G D P$ will be $\beta_{1}+\beta_{5}$, the coefficient on $G D P^{2}$ will be $\beta_{2}+\beta_{6}$, and likewise for the constant $\left(\beta_{0}+\beta_{4}\right)$ and Growth $\left(\beta_{3}+\beta_{7}\right)$. PACL's Table 2.12 correctly reports these summed coefficients in the columns labeled "Transitions to democracy" (the second column of our Table 1), but the reported $\mathrm{P}$-values are those for $\beta_{4}$ through $\beta_{7}$ alone, rather than for the summed coefficients.

To calculate the $\mathrm{P}$-values for transitions to democracy, one must perform a Wald test on the hypothesis that the sum of the appropriate coefficients is $0 .^{3}$ For example, the coefficient on $\beta_{1}$ in Equation 1 is -0.201 , with a P-value of 0.162 , and the coefficient on $\beta_{5}$ is -0.128 with a $\mathrm{P}$-value of 0.484 . The sum of the coefficients is -0.329 , and PACL then

\footnotetext{
${ }^{2}$ Relative to PACL's Table 2.12, the coefficients on GDP and GDP ${ }^{2}$ in Table 1 are multiplied by 1000.

${ }^{3} \mathrm{~A}$ Wald test is used to determine whether a linear combination of coefficient values is equal to some constant. Here we wish to test the restriction that, for instance, $\beta_{1}+\beta_{5}=0$. See Greene (2003), pp. 484-88. All Wald tests were performed using the post-estimation test command in Stata 9.0. Note that these same P-values can also be calculated by running two probits, one when the regime at time $t-1$ is democratic and another when it is a dictatorship.
} 
Table 1: Results from PACL Table 2.12

\begin{tabular}{llll}
\hline Indep. Var. & Democ. $\rightarrow$ Autoc. & $\begin{array}{l}\text { Autoc. } \rightarrow \text { Democ. } \\
\text { (Original) }\end{array}$ & $\begin{array}{l}\text { Autoc. } \rightarrow \text { Democ. } \\
\text { (Corrected) }\end{array}$ \\
\hline Constant & $-1.144^{* *}$ & $-2.524^{* *}$ & $-2.524^{* *}$ \\
& $(0.000)$ & $(0.000)$ & $(0.000)$ \\
\cline { 2 - 4 } GDP & -0.201 & 0.329 & $0.329^{* *}$ \\
& $(0.162)$ & $(0.484)$ & $(0.004)$ \\
\cline { 2 - 4 } GDP & -0.003 & -0.029 & -0.029 \\
& $(0.874)$ & $(0.191)$ & $(0.069)$ \\
GDP Growth & $-0.042^{* *}$ & $-0.021^{* *}$ & $-0.021^{*}$ \\
& $(0.003)$ & $(0.000)$ & $(0.015)$ \\
\hline N & 1584 & 2407 & 2407 \\
Pseudo $R^{2}$ & 0.19 & 0.05 & 0.05 \\
\hline
\end{tabular}

Note: P-values in parentheses. * denotes significance at the 0.05 level; $* *$ denotes significance at the 0.01 level.

correctly reverse the sign to indicate the impact of $G D P$ on transitions from dictatorship to democracy. ${ }^{4}$

What these results tell us is that the impact of GDP on transitions to dictatorships is not significantly different from 0 , and that the impact of GDP on transitions to democracy is not significantly different from its impact on transitions to dictatorship; that is, -0.329 is not significantly different from -0.201. But in this context we are interested in whether the sum of these coefficients is different from 0: that is, whether GDP is a significant predictor of transitions to democracy. And a Wald test of the hypothesis that $\beta_{1}+\beta_{5}=0$ shows that it can be rejected with a P-value of 0.004 .

Substituting the corrected $\mathrm{P}$-values into the analysis yields the results reported in the last column of Table 1. As shown, these results actually run counter to PACL's central hypothesis: GDP influences transitions to democracy but not transitions to autocracy.

Both the GDP and GDP $P^{2}$ terms, however, contribute to the total impact of GDP on transitions. To evaluate this impact, we employ the delta method, which involves evaluating the derivative $\partial P / \partial G D P$. For Equation 1, the derivative is:

$$
\Phi^{\prime}\left(\beta_{0}+\beta_{1} G D P+\beta_{2} G D P^{2}+\beta_{3} \text { Growth }\right) \cdot\left(\beta_{1}+2 \beta_{2} G D P\right)
$$

when $I_{D}=0$, and

$$
\begin{gathered}
\Phi^{\prime}\left[\left(\beta_{0}+\beta_{4}\right)+\left(\beta_{1}+\beta_{5}\right) G D P+\left(\beta_{2}+\beta_{6}\right) G D P^{2}+\left(\beta_{3}+\beta_{7}\right) \text { Growth }\right] \\
\cdot\left[\left(\beta_{1}+\beta_{5}\right)+2\left(\beta_{2}+\beta_{6}\right) G D P\right]
\end{gathered}
$$

\footnotetext{
${ }^{4}$ The -0.329 coefficient indicates the impact of GDP on transitions from dictatorship to dictatorship, which is equal and opposite to its impact on transitions to democracy.
} 
when $I_{D}=1$. Performing these calculations, we find that the overall coefficient on GDP for transitions to autocracy is -0.0034 with a standard error of 0.0015 , and for transitions to democracy the coefficient is -0.011 with a standard error of 0.0034 . The total impact of GDP on regime change is thus significant in both directions, rather than insignificant both ways as reported by PACL.

PACL's Table 2.17, reproduced as the first two columns of Table 2, reports the results from another Markov regression, this time without $G D P^{2}$ but with a host of other covariates. The authors acknowledge that the coefficient on GDP is now significant in both directions, but discount this result, saying that "it is orders of magnitude larger for democracies." (p. 123) They do not indicate the basis for this statement. ${ }^{5}$

As with Table 2.12, however, PACL fail to report the significance level of the sum of the relevant coefficients. The corrected version of these results is shown in the third column of Table 2. This time the revised results are more favorable to their central hypothesis: GDP is a significant predictor of transitions to autocracy but not to democracy. These results, however, are far from dispositive, as they are highly sensitive to model specification. ${ }^{6}$ PACL's results thus leave open the central issue: the significance of GDP in transitions to democracy.

\section{A Trichotomous Measure of Democratization}

Among the most hotly debated issues in the study of democratization is that of the choice of measures (see, for example, Bollen and Jackman 1989; Collier and Adcock 1999; Munck and Verkuilen 2002). We begin this section by defining and summarizing our three-fold categorization. We then describe our measure of a country's previous history of democratization and the other independent variables of our analysis.

\section{Identifying Partial Democracies}

PACL employ a dichotomous measure of democracy. Consider, however, the 85 authoritarian regimes that Geddes (1999, pp. 115-16) records as having collapsed during the "third wave." Of these, 34 re-emerged as authoritarian regimes, and 30 as stable democracies; 21 others, however, remained contested and unstable, she notes, and of these, four descended into "warlordism." Geddes' discussion thus reminds us of the significance of partial democracies, a category that dichotomous measures fail to - indeed, cannot capture. $^{7}$

Using the Polity IV scaling of regimes from -10 to +10 , we categorize regimes as Autocracies (Polity value -10 to 0), Partial Democracies $(+1$ to +7 ), or (Full) Democracies

\footnotetext{
${ }^{5}$ Indeed, this is one of the criticisms leveled at PACL by Boix and Stokes (2003). We discuss their results at further length below.

${ }^{6}$ For example, in most specifications the inclusion of the Previous Transitions variable (labeled "STRA" in PACL) makes the coefficient on GDP insignificant. But an examination of the data patterns indicates that the greater the number of previous transitions, the less of an effect GDP has on the outcome. This in turn suggests including an interactive term, and indeed when this term is added all three variables (GDP, STRA, and GDP*STRA) are significant.

${ }^{7}$ This division is also emphasized in Collier and Levitsky (1997).
} 
Table 2: Results from PACL Table 2.17

\begin{tabular}{|c|c|c|c|}
\hline Indep. Var. & Democ. $\rightarrow$ Autoc. & $\begin{array}{l}\text { Autoc. } \rightarrow \text { Democ } . \\
\text { (Original) }\end{array}$ & $\begin{array}{l}\text { Autoc. } \rightarrow \text { Democ. } \\
\text { (Corrected) }\end{array}$ \\
\hline Constant & $\begin{array}{l}0.114 \\
(0.899)\end{array}$ & $\begin{array}{l}3.414^{* *} \\
(0.002)\end{array}$ & $\begin{array}{l}3.414^{* *} \\
(0.000)\end{array}$ \\
\hline$G D P$ & $\begin{array}{l}-0.547^{* *} \\
(0.000)\end{array}$ & $\begin{array}{l}-0.033^{* *} \\
(0.000)\end{array}$ & $\begin{array}{l}-0.033 \\
(0.445)\end{array}$ \\
\hline GDP Growth & $\begin{array}{l}-0.022 \\
(0.181)\end{array}$ & $\begin{array}{l}0.018^{*} \\
(0.027)\end{array}$ & $\begin{array}{l}0.018 \\
(0.079)\end{array}$ \\
\hline $\begin{array}{l}\text { Leadership } \\
\text { Turnover }\end{array}$ & $\begin{array}{l}0.975^{* *} \\
(0.001)\end{array}$ & $\begin{array}{l}-0.527^{* *} \\
(0.000)\end{array}$ & $\begin{array}{l}-0.527^{* *} \\
(0.007)\end{array}$ \\
\hline $\begin{array}{l}\text { Religious } \\
\text { Fractionalization }\end{array}$ & $\begin{array}{l}0.026^{* *} \\
(0.010)\end{array}$ & $\begin{array}{l}-0.001^{*} \\
(0.014)\end{array}$ & $\begin{array}{l}-0.001 \\
(0.816)\end{array}$ \\
\hline \% Catholic & $\begin{array}{l}3.937^{*} \\
(0.048)\end{array}$ & $\begin{array}{l}-0.369 \\
(0.105)\end{array}$ & $\begin{array}{l}-0.369 \\
(0.707)\end{array}$ \\
\hline$\%$ Protestant & $\begin{array}{l}2.626^{*} \\
(0.039)\end{array}$ & $\begin{array}{l}0.038 \\
(0.118)\end{array}$ & $\begin{array}{l}0.038 \\
(0.965)\end{array}$ \\
\hline$\%$ Moslem & $\begin{array}{l}5.087^{*} \\
(0.016)\end{array}$ & $\begin{array}{l}-0.147 \\
(0.932)\end{array}$ & $\begin{array}{l}-0.147 \\
(0.890)\end{array}$ \\
\hline $\begin{array}{l}\text { New } \\
\text { Country }\end{array}$ & $\begin{array}{l}-0.012 \\
(0.978)\end{array}$ & $\begin{array}{l}0.432 \\
(0.365)\end{array}$ & $\begin{array}{l}0.432^{*} \\
(0.039)\end{array}$ \\
\hline $\begin{array}{l}\text { British } \\
\text { Colony }\end{array}$ & $\begin{array}{l}-0.842^{*} \\
(0.048)\end{array}$ & $\begin{array}{l}-0.164 \\
(0.153)\end{array}$ & $\begin{array}{l}-0.164 \\
(0.423)\end{array}$ \\
\hline $\begin{array}{l}\text { Previous } \\
\text { Transitions }\end{array}$ & $\begin{array}{l}0.897^{* *} \\
(0.000)\end{array}$ & $\begin{array}{l}-0.362^{* *} \\
(0.000)\end{array}$ & $\begin{array}{l}-0.362^{* *} \\
(0.000)\end{array}$ \\
\hline $\begin{array}{l}\% \text { World } \\
\text { Democracies }\end{array}$ & $\begin{array}{l}-3.735^{*} \\
(0.047) \\
\end{array}$ & $\begin{array}{l}-3.040 \\
(0.750)\end{array}$ & $\begin{array}{l}-3.040^{*} \\
(0.011)\end{array}$ \\
\hline $\begin{array}{l}\mathrm{N} \\
\text { Pseudo } R^{2}\end{array}$ & $\begin{array}{l}1584 \\
0.19\end{array}$ & $\begin{array}{l}2407 \\
0.05\end{array}$ & $\begin{array}{l}2407 \\
0.05\end{array}$ \\
\hline
\end{tabular}

Note: P-values in parentheses. * denotes significance at the 0.05 level; $* *$ denotes significance at the 0.01 level. 
$(+8$ to +10$) .8$ The Polity score is based on three components: measures of executive constraints, political competition, and the quality of political participation. In autocracies, the executive retains a high level of political discretion, often due to the absence of a strong judiciary or powerful legislature. There is no organized competition for political office. And political participation is orchestrated by those who hold power. In full democracies, the executive faces binding constraints on the use of power; there are institutionalized forms of political competition; and citizens openly propound and associations openly champion civic causes.

Between these end points, there remain gradations: in partial democracies, the chief executive may be elected, but then face weak constraints; and his selection may not result from open and organized competition, but rather from lobbying by a politicized military or from selection by a committee of a ruling party. Alternatively, the election itself could be uncompetitive, either because of political manipulation by the authorities or because political parties were highly factionalized. As of 2002 (Polity scores in parentheses), Ethiopia (1), Nigeria (4), Venezuela (6), and Russia (7) illustrate what is meant by "partial democracy."

While the selection of the cut points must ultimately be arbitrary, we provide three justifications. When the Polity score registers 7 or below, then the country fails to attain a maximum score on any of its three component measures. Countries with 8 or higher reach a maximum value on at least one of them; 9 or higher, on at least two; and 10 on all three. Secondly, the Polity scores yield classifications that correspond well with those employed by others. Most importantly, as noted in the discussion below, we can readily recover the classification employed by PACL using the Polity scores. Lastly, our argument is robust to changes in the cut points: we estimated the regressions reported later in the paper with the cutpoints between adjacent categories moved one or two units in either direction, and the results did not change. In this sense, our findings are not the result of an arbitrary choice of measure.

Thus defined, partial democracies comprise $14.3 \%$ of country-years in our sample, which includes 169 countries from 1960 to 2000. As Figure 1 shows, the percentage of partial democracies among the world's societies has grown markedly in recent years: it had a minimum value of $3.6 \%$ in 1976 and rose to its maximum of $26.1 \%$ in 2000 , with a notable increase after the fall of the Soviet Union. The "third wave" peopled the globe with partial democracies.

Whereas Figure 1 shows the overall patterns of democratization, Table 3 examines the dynamics of change from one regime category to another. It shows the distribution of autocracies, partial democracies, and democracies, conditioning on the previous year's category. The table reveals that both autocracies and full democracies are stable in the short run: an average of $97.3 \%$ of all autocracies remain autocratic the next year, while an average of $98.2 \%$ of all democracies remain democratic; thus around $2 \%$ of countries in these categories change in a given year. Partial democracies are over four times less stable,

\footnotetext{
${ }^{8}$ Note that by our definition, partial democracies are truly an intermediate category, even relative to PACL's regime classification formula. In the country-years for which our data sets overlap, $97 \%$ of regimes that we code as autocratic PACL also code as autocracies, and $92 \%$ of our full democracies are democracies in their data too. But of our partial democracies, $52 \%$ are democracies and $48 \%$ are autocracies by PACL's measure.
} 


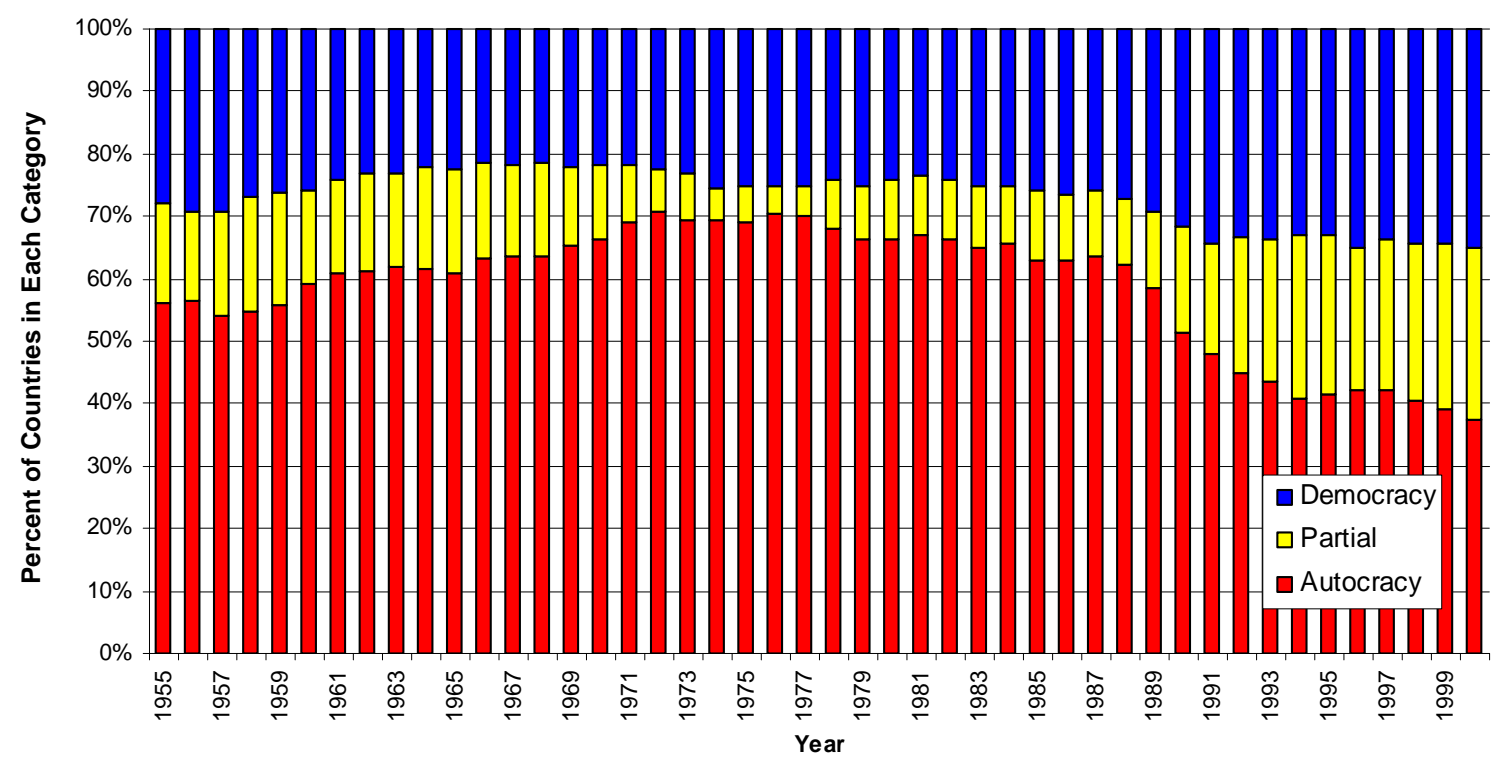

Figure 1: World Democratization Trends, 1960-2000

however, with $9.6 \%$ of them changing into an autocracy or full democracy the following year.

Table 3: Regime Category Transitions - One Year Lag

\begin{tabular}{lrrr}
\hline & \multicolumn{3}{c}{ Current Year } \\
\cline { 2 - 4 } Previous Year & Autocracy & Partial Democracy & Democracy \\
Autocracy & $97.3 \%$ & $2.1 \%$ & $0.7 \%$ \\
& $(3,121)$ & $(66)$ & $(22)$ \\
Partial Democracy & $6.4 \%$ & $90.4 \%$ & $3.3 \%$ \\
& $(49)$ & $(695)$ & $(25)$ \\
Democracy & $1.1 \%$ & $0.8 \%$ & $98.2 \%$ \\
& $(16)$ & $(12)$ & $(1,496)$ \\
Total & 3,186 & 773 \\
\hline \multicolumn{2}{c}{1,543} \\
\cline { 2 - 4 }
\end{tabular}

These differences become even more pronounced when we expand the time horizon to five years. About $11 \%$ of all autocracies change into partial or full democracies after five years, and $7 \%$ of democracies change category five years later. The most volatile group, again by a large margin, is partial democracy: almost $40 \%$ of these change category after five years. Movements in or out of the category of partial democracy account for $80 \%$ of the transitions in our sample. ${ }^{9}$

\footnotetext{
${ }^{9}$ Appendix 1 provides a complete categorization of countries by their number and type of transitions.
} 
These data highlight the importance of partial democracies: more volatile than either pure democracies or autocracies, they account for an increasing portion of current regimes and the lion's share of regime transitions. Rather than dichotomizing countries into democracies and autocracies, then, our dependent variable will be trichotomous, including a middle category for partial democracy. This variable is called Regime Category in our dataset, with Autocracies coded as 0, Partial Democracies as 1, and Full Democracies as 2. In creating a three-category democracy measure, we heed the advice of both Elkins (2000), who warns that dichotomous measures may obscure correlations that intermediate-graded scales reveal, and Collier and Adcock (1999), who suggest that for studies of democratic transitions, more coarse-grained measures are appropriate.

\section{Previous Democratization}

Many observers argue that a country's previous transition history may affect current efforts at democratization, as prior failures may spur or weaken future attempts. Goldstone and Kocornik-Mina (2005) have shown that many countries experiencing democratic transitions are "bouncers" or "cyclers" that move back and forth between autocracy and democracy on multiple occasions. We somehow need to capture prior volatility and failed efforts at achieving democracy.

Despite its importance, however, a country's history of negative experience with democratization is hard to measure. Simply counting movements between categories will miss unstable behavior that consists of substantial movements toward (or away from) democracy within a single category: say from a Polity score of -10 to 0 and then back to -10 . Counting the value of all changes in Polity scores, on the other hand, will treat successful and large transitions to democracy as indicating just as much volatility as a country that experiences several smaller movements toward democracy that failed and fell back.

We therefore settled on a variable "Previous Transitions," which for country $i$ in year $t$ is the cumulative sum of the absolute values of negative changes in the Polity score for country $i$ from 1960 up to and including year $t$. To illustrate the construction of this variable, Figure 2 provides the values of both the Polity score and the Previous Transitions variable for Turkey for each sample year. As the figure shows, the Polity score for Turkey varied widely over this period, from 4 up to 9 , down to -2 , back up to 9 , back down to -5 , up to 9 , and then finally down to 7 . Most measures would show that Turkey fell out of democracy twice during the sample period, and, indeed, our measure rises at just those points where the Polity score falls. At any given time then, the variable provides an indicator of the country's prior and cumulative negative experiences with democratization. ${ }^{10}$

\section{Other Independent Variables}

As independent variables, we employ the standard set of modernization indicators: log of GDP per capita, year-to-year GDP growth, the percent of the population living in cities,

\footnotetext{
${ }^{10}$ We note also that our Previous Transitions measure correlates with PACL's similar "STRA" variable (for sum of transitions to authoritarianism) at $90.5 \%$ for all overlapping country-years.
} 


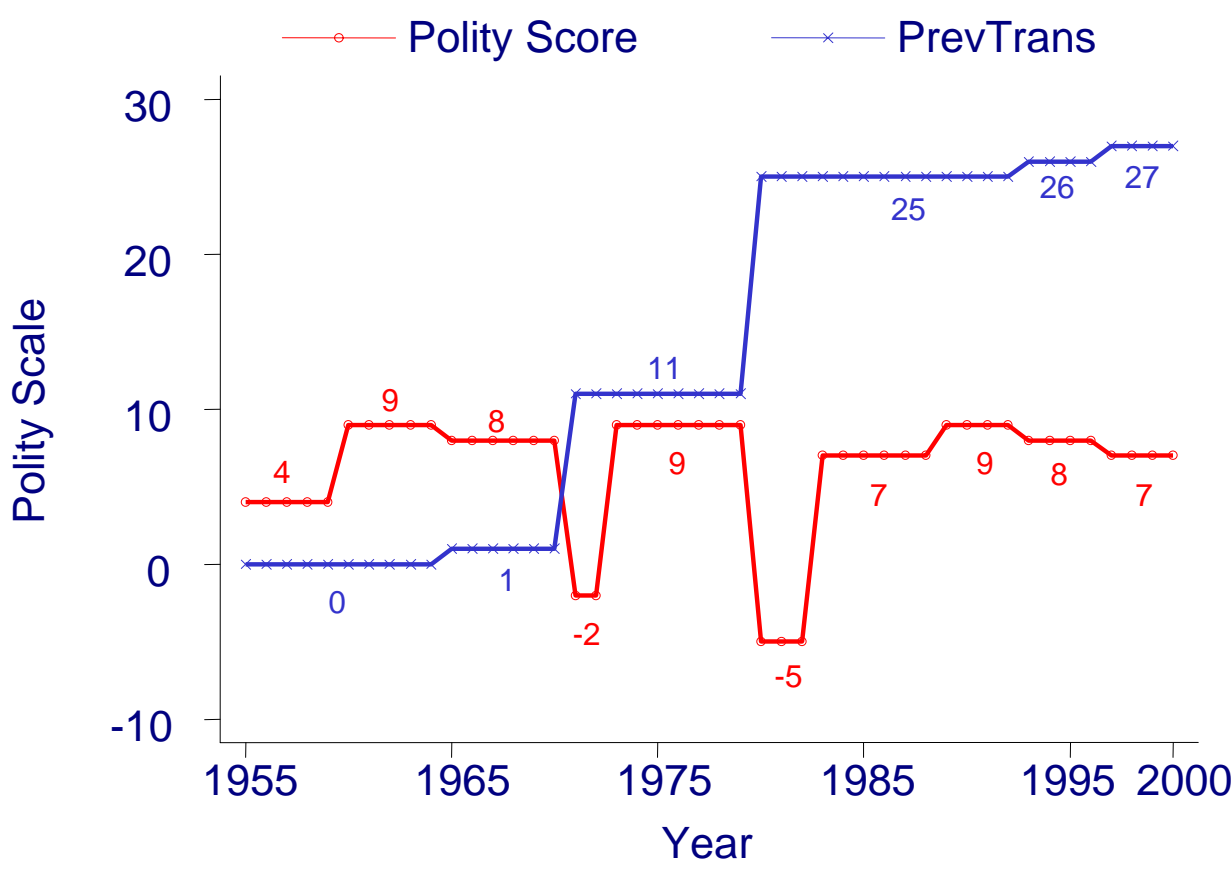

Figure 2: Illustration of Previous Transitions variable for Turkey, 1960-2000

and $\log$ of population density. ${ }^{11}$ Our focus will, of course, be on per capita GDP.

As controls, we use our Previous Transitions measure of prior experiences with democratization (as in Acemoglu and Robinson 2001); log of trade openness, defined as exports plus imports over GDP (as in Rodrik 1997); and a variable indicating whether over $75 \%$ of national income is derived from sales of minerals or petroleum. This latter variable captures the "resource curse" hypothesis (as in Ross 1999 and Boix and Stokes 2003), which argues that countries deriving a large share of national income from easily extractable natural resources tend to be undemocratic and unstable. Table 4 provides descriptive statistics for all variables. ${ }^{12}$

\section{$5 \quad$ Statistical Methodology}

We address two distinct questions: what makes countries democratic, and what factors help insure new democracies against backsliding to autocracy? The first refers to democratization; the second, to consolidation. We use two techniques to address the

\footnotetext{
${ }^{11}$ One might also add percent of GDP originating from agriculture to this list, but its correlation with urbanization is over $90 \%$. Thus we use only urbanization in our analysis.

${ }^{12}$ Data Sources: Polity Score-Polity V, IRIS, University of Maryland; GDP_Penn World Tables; Urban Population-Population Division of the Department of Economic and Social Affairs of the United Nations; Population Density - Hybrid of UN Population Division, World Development Indicators, and Banks population density series (WDI is used if UND is not available; BNK is used if WDI is not available); Trade Openness - Hybrid data series of World Development Indicators and Penn World Tables trade openness (WDI is the primary source; PWT is used if WDI is missing); Resource Curse-United Nations: Trade and Development Statistics.
} 
Table 4: Summary Statistics

\begin{tabular}{lccccc}
\hline \hline \multicolumn{1}{c}{ Variable } & Mean & Std. Dev. & Min. & Max. & N \\
\hline Polity Score & -0.45 & 7.58 & -10 & 10 & 5671 \\
Regime Category & 0.70 & 0.88 & 0 & 2 & 5671 \\
Log of Per Capita GDP & 8.14 & 1.04 & 5.64 & 10.21 & 4417 \\
Percent Change in GDP & 0.02 & 0.06 & -0.52 & 1.01 & 4475 \\
Percent Urban Pop. & 44.94 & 24.29 & 2.3 & 100 & 5245 \\
Log of Population Density & 3.61 & 1.46 & -0.49 & 8.77 & 5600 \\
Log of Trade Openness & 3.98 & 0.62 & 0.43 & 6.16 & 4902 \\
Previous Transitions & 3.96 & 6.41 & 0 & 31 & 5671 \\
Resource Curse & 0.23 & 0.42 & 0 & 1 & 5671 \\
\hline
\end{tabular}

former - tobit and Markov analyses - and one to address the latter - duration analysis.

First, we shall examine democratization using a method that takes into account the censoring of our data; that is, our scale is limited to the -10 to +10 range, perhaps artificially. We employ a double-censored tobit model for these estimations, which uses the full range of Polity values rather than categories or ranges of values.

Like PACL, we also use Markov transition models. However, as described above, instead of their two-state model (democracy and dictatorship), we shall use a three-state model. This allows us to estimate six distinct transitions: Autocracy to Partial Democracy, Partial Democracy to Democracy, and Autocracy to Democracy, as well as the reverse of each. The Markov model treats each of these six transitions as distinct and identifies causal factors associated with each kind of change.

Developed in biometrics, duration models estimate the impact of factors affecting survival. In our setting we wish to determine the factors that affect the survival of newlyfledged democracies. Our analysis differs from the classic medical setting, though, in that each "patient" (or country, for us) can experience more than one episode of failure; it can fall out of democracy more than once (witness Turkey). Hence we employ a repeatedfailures variant of the standard duration model. ${ }^{13}$ We wish to capture unit-specific effects: i.e., whether some countries are more "frail" (to return to a medical setting), in the sense of being (to return once again to our application) more prone to autocracy.

\section{Continuous Models with Data Censoring}

Tobit models account for the possibility that the data are censored at either or both ends of their range of values. That is, we assume, for country $i$ at time $t$ :

$$
\begin{array}{r}
Y_{i t}^{*}=X_{i t} \beta+\epsilon_{i t}, \epsilon_{i t} \sim N\left(0, \sigma^{2}\right), \\
Y_{i t}=Y_{i t}^{*} \text { if } a \leq Y_{i t}^{*} \leq b ; Y_{i t}=a \text { if } Y_{i t}^{*}<a ; Y_{i t}=b \text { if } Y_{i t}^{*}>b,
\end{array}
$$

where $Y_{i t}^{*}$ is the implicit, or underlying value of the dependent variable, $Y_{i t}$ is its observed value, and $a$ and $b$ are the upper and lower bounds of the observation interval, respectively.

\footnotetext{
${ }^{13}$ These models are becoming increasingly popular in political science, and our treatment of them owes much to recent work by Box-Steffensmeier and Zorn (2002).
} 
(For the Polity scale used in this study, $a=-10$ and $b=+10$.) This gives rise to the likelihood function:

$$
\prod_{a \leq Y_{i t}^{*} \leq b}\left[\frac{1}{\sigma} \phi\left(\frac{1}{\sigma}\left(Y_{i t}-X_{i t} \beta\right)\right)\right] \prod_{Y_{i t}^{*}<a}\left[\Phi\left(\frac{1}{\sigma}\left(a-X_{i t} \beta\right)\right)\right] \prod_{Y_{i t}^{*}>b}\left[\Phi\left(-\frac{1}{\sigma}\left(b-X_{i t} \beta\right)\right)\right] .
$$

The first term corresponds to non-limit observations, the second to observations at the lower limit $a$, and the third to observations at the upper limit $b .{ }^{14}$

The tobit methodology gives accurate estimates for processes in which data are limited to some predetermined range. It also allows for the estimation of the percent of censored observations, in order to determine the degree to which the upper and lower limits constrain the estimation.

This part of the estimation, then, takes advantage of the full 21 point Polity scale. However, the technique assumes that moves up the Polity scale are caused by factors equal and opposite to those driving moves down the scale. As PACL have shown, it is often the case that a given factor may have a different impact on transitions toward, or away from, greater democracy. We therefore supplement the tobit analysis with a Markov switching model.

\section{Markov Transition Models}

The Markov model employs a smaller number of possible democratization categories and then estimates the probability of moving from any given state to another state in a single period. In these models, history matters: the conditions present in one period can affect the probabilities of different types of transitions in the subsequent period. ${ }^{15}$ Markov models thus estimate equations of the form:

$$
F\left[\operatorname{Pr}\left(Y_{i t}=b \mid Y_{i t-1}=a\right)\right]=\theta_{a b}+X_{i t} \beta_{a},
$$

where $a$ and $b$ are possible regime types and $F(\cdot)$ is a function from the $[0,1]$ interval to the real line, such as the $\operatorname{logit}\left(F(z)=\log \frac{z}{1-z}\right)$ or probit $\left(F(z)=\Phi^{-1}(z)\right)$ functions.

To expedite the analysis, we follow Clayton (1992) and work with cumulative transition probabilities. Assume that there are $C$ ordered categories of the dependent variable $(C=3$ for our study), labeled $0,1, \ldots, C-1$. It then becomes convenient to express the equations in terms of $Y^{*}$ variables, where $Y_{a}^{*}=1$ if $Y \leq a$. In our data, for example, if we let $Y_{i t}=0$ indicate that country $i$ is an autocracy at time $t, Y_{i t}=1$ indicate partial democracy, and $Y_{i t}=2$ indicate full democracy, then the translation from $Y$ to $Y^{*}$ is given in Table 5.

As by definition, $\operatorname{Pr}(Y \leq a)=\operatorname{Pr}(Y \leq a-1)+\operatorname{Pr}(Y=a)$, we can recover the individual transition probabilities from the set of cumulative probabilities. We therefore estimate equations of the form:

$$
F\left[\operatorname{Pr}\left(Y_{i t}=b \mid Y_{i t-1} \leq a\right)\right]=\theta_{a b}+X_{i t} \beta_{a},
$$

\footnotetext{
${ }^{14}$ See Greene (2003), pp. 764-66 for a good textbook discussion of these models.

${ }^{15}$ Variables associated with other historical aspects of a country's development, such as previous transitions to democracy, can be added to the model as independent variables. See the discussion of our Previous Transitions variable above.
} 
Table 5: Definition of $Y^{*}$ Variables

\begin{tabular}{llll}
\hline$Y:$ & 0 & 1 & 2 \\
\hline$Y_{0}^{*}:$ & 1 & 0 & 0 \\
$Y_{1}^{*}:$ & 1 & 1 & 0 \\
\hline
\end{tabular}

for $b=0,1,2$ and $a=0,1$, which is equivalent to Equation 6, substituting values of $Y^{*}$ for values of $Y$ in the previous period. One could estimate Equation 7 separately for each regime type, or, as with dichotomous Markov regressions, combine the data for each value of $b$ into a single equation, including interactions of the independent variables and lagged values of $Y^{*}$ :

$$
F\left[\operatorname{Pr}\left(Y_{i t}=b \mid Y_{i t-1}^{*}=y_{i t-1}^{*}\right)\right]=\theta_{b}+\sum_{\ell=0}^{1} \alpha_{\ell b} y_{i t-1 \ell}^{*}+x_{i t}\left(\beta+\sum_{\ell=0}^{1} \gamma_{\ell} y_{i t-1 \ell}^{*}\right),
$$

for $b=0,1,2$. Under this formulation, $\theta_{b}=\theta_{C-1}$ and $\alpha_{a b}=\theta_{a b}-\theta_{(a+1) b}$, so a significant value for the $\alpha$ terms indicates that adjacent categories should not be combined together. Similarly, $\beta=\beta_{C-1}$ and $\gamma_{a}=\beta_{a}-\beta_{a+1}$, so insignificant $\gamma$ values indicate that an independent variable has similar effects on transition probabilities for adjacent categories of the lagged dependent variable.

A distinctive advantage of this approach, then, is that we can test whether adjacent categories of our dependent variable should be collapsed. As we shall see, this feature enables us to test the validity of our own three-way classification; to compare it to PACL's two-way categorization; and to explore the significance of that comparison. Given our three-way division of regime types, for example, a Markov model of regime type on GDP indicates that none of the adjacent categories should be combined. But if we add a fourth type - "partial autocracies" with Polity scores between -6 and 0 - the same test indicates that the full and partial autocracies should indeed be combined into a single regime category.

Equation 8 can be run separately for each value of $b$ or with an ordered probit, where the dependent variable is the ordered regime category. We begin with a "fully saturated" model, with right-hand side variables consisting of the lagged regressors (GDP, growth, urbanization, etc.), the lagged values of the indicator variables $Y_{0}^{*}$, lagged $Y_{1}^{*}$, and all interactions between the regressors and indicators. From this initial model, with its profusion of interactive terms, one tests down, eliminating insignificant interactions to arrive at a more parsimonious specification. ${ }^{16}$ It is the result of this procedure that we report.

\section{Survival Analysis}

To investigate the determinants of consolidation, we employ duration models. As mentioned above, our application differs from that in biometrics in two important ways:

\footnotetext{
${ }^{16}$ This procedure is elaborated in Chapter 10 of Diggle, Liang, and Zeger (2002).
} 
we think that countries might have unit-specific heterogeneity, and we know that they may experience repeated failure.

In duration models, unit-specific effects are captured by "frailty" terms, written as

$$
h_{i}(t)=\lambda_{i}(t) \nu_{i}
$$

where $h_{i}(t)$ is the hazard rate for observation $i$ at time $t$ and $\nu_{i}$ is an individual-specific factor which operates multiplicatively on the hazard. In biometrics, this term captures the patient-specific susceptibility to a disease; in our setting, it refers to a country's susceptibility to autocracy. If countries differ in their frailties, but these terms are left out of the estimating equation, then there will be more variability in the actual hazard than is captured by the model (Omori and Johnson 1993). Over time, differences in frailty will cause observations to "select out" of the data; that is, low-frailty cases will stay in, while high-frailty ones will drop out. The model will then underestimate the hazard, with a corresponding overestimate of survival times. Not only is the shape of the hazard function incorrectly estimated; if the $\nu_{i}$ terms are correlated with the independent variables, then the estimated coefficients will also be biased.

Analogously with panel data, these unit-specific effects can be estimated via fixed or random effects. Following Lancaster (1990), we adopt the random-effects approach, which involves choosing a specific distribution for the $\nu_{i}$ 's; the most commonly-used is the gamma $(1, \theta)$ distribution. ${ }^{17}$

For the estimation, we first fit a standard proportional hazards model, and then choose a set of possible values for $\theta$. For each of these values, we generate an estimated "predicted frailty" for each observation. We then fit a second duration model, this time including the estimated $\nu_{i}$ terms as an additional covariate, with a fixed coefficient of 1.0 (that is, as an offset):

$$
h(t)=h_{0}(t) \hat{\nu}_{i} \exp \left(X_{i} \beta\right) .
$$

We then repeat these steps for each value of $\theta$ until convergence.

A second distinctive characteristic of our data is that we can have repeated failurescountries can fall out of democracy more than once - and we would not wish to impose $a$ priori the requirement that these failures be independent of one another. In particular, methods that ignore correlations among repeated failures will tend to underestimate the standard errors.

To address this property, we require that our frailty terms not be independent, but rather correlated across all observations from a single country. The unit of observation thus becomes a "country-spell;" that is, a sequential run of years in which a given country remains in a single regime. We then restrict the estimated frailty terms to be constant (in parlance, "shared") for all observations from a given country. The approach, once again, is to test down: i.e., to start with a proportional hazards model with shared frailties, and if these are not significant, then to remove this requirement and estimate a less restricted model instead.

\footnotetext{
${ }^{17}$ See also Vaupel et. al. (1979) and Manton et. al. (1981).
} 


\section{$6 \quad$ Regression Results}

To assess the validity of this claim, we proceed to analyze the results from the tobit, Markov, and survival analyses described above. In each case, we estimate three models: GDP alone; GDP plus the other modernization variables; and GDP, modernization, and political control variables. The Tobit regressions also include a lagged dependent variable and control for regional effects: Africa, East Asia, Europe, Former Soviet Union, Latin America, and Near East. ${ }^{18}$

\section{Tobit Regressions}

The tobit results are given in Table 6. As indicated, GDP is significant in all specifications: countries are more likely to be democratic the higher their level of economic development. Moreover, the overall model fit is good, with a pseudo- $R^{2}$ of about $40 \%$, high enough to capture significant amounts of variation, but not so high that one would suspect that the lagged dependent variable was doing all the work.

Table 6: Tobit regression analysis of factors affecting democratic transitions (regional fixed effects omitted)

\begin{tabular}{lccc}
\hline & \multicolumn{3}{c}{ Model } \\
\cline { 2 - 4 } & $(1)$ & $(2)$ & $(3)$ \\
\hline Lagged Polity Score & .964 & .962 & .962 \\
& $(.006)^{* * *}$ & $(.007)^{* * *}$ & $(.007)^{* * *}$ \\
GDP Per Capita & .362 & .385 & .32 \\
GDP Growth & $(.063)^{* * *}$ & $(.099)^{* * *}$ & $(.102)^{* * *}$ \\
& & -2.458 & -2.72 \\
Pct. Urban Pop. & & $(.782)^{* * *}$ & $(.783)^{* * *}$ \\
& & 0 & -.003 \\
Population Density & & $(.004)$ & $(.004)$ \\
& & .059 & .032 \\
Trade Openness & & & $(.035)^{*}$ \\
& & & $.036)$ \\
Previous Transitions & & & $.077)^{* * *}$ \\
& & & .013 \\
Resource Curse & & & $-.067)^{* *}$ \\
& & & $(.113)$ \\
N & & 3789 & 3789 \\
Pseudo- $R^{2}$ & .3259 & .397 & .398 \\
\hline
\end{tabular}

Note: All independent variables lagged one year. ${ }^{*}=.10 ; * *=.05 ; * * *=.01$.

\footnotetext{
${ }^{18}$ The countries in each region are listed in Appendix 2.
} 
The regression results also highlight some interesting regularities. First, note that higher GDP growth rates are associated with autocracies. On its own this finding might be puzzling, but see the Markov analysis below, which indicates that this relation holds only for countries starting in autocracy. Looking at the other two modernization variables, urbanization is negatively related to democracy and population density is positively related, but neither relation is statistically significant.

As for the political variables, the results on PrevTrans, our measure of previous attempts at democratization, indicate that countries that experience previous falls from democracy tend to be more democratic (but, again, see the discussion of this variable in the Markov regressions below). Trade openness is also associated with more democracy. And the "resource curse" is negatively related to democracy, but the coefficient is insignificant.

These findings corroborate previous results linking economic development to democracy, but they are, of course, subject to PACL's objection that modernization variables may describe well those countries already in democracy but do not predict transitions out of autocracy. This possibility is addressed in the Markov transition analysis below.

\section{Markov Regressions}

As a first look at the data, consider Figure 3, which shows a local regression (lowess) plot of logged GDP per capita and the probability of transitions in or out of full democracy. The most obvious pattern is that GDP does seem to have a significant impact on the probability of transition both into and out of democracy, and with roughly similar magnitudes. This initial view of the data induces skepticism regarding PACL's claim that GDP impacts transitions from but not into democracy.

PACL also make much of the fact that no democracy has ever fallen with a GDP per capita greater than $\$ 6,055$, the prevailing level of income in Argentina when it transitioned to autocracy in 1975. They thus imply that the probability of transitioning to autocracy falls sharply once a country passes this key income level. As shown in Figure 3, though, no sharp dropoff is evident; the probability of leaving democracy declines smoothly as GDP increases, without any indication that one level of wealth is more critical than another.

PACL also claim that the income levels at which countries transition out of autocracy show significantly more variation than the levels at which countries transition out of democracy. Figure 4 shows that the data do not support PACL's claim: the distribution of GDP values for transitions to democracy actually has a slightly smaller variance than the distribution of income for transitions to autocracy (0.712 vs. 0.742).

We begin our Markov analysis with all possible interactions between the regressors and lagged values of $Y_{0}^{*}$ and $Y_{1}^{*}$, and then test down to a more parsimonious model. Recall that if, for example, the interaction between GDP and $Y_{0}^{*}\left(G D P * Y_{0}^{*}\right)$ is significant, this means that GDP has a different effect on the level of democracy if the regime is autocratic in the previous period, as opposed to partially or fully democratic. Similarly, if $G D P * Y_{1}^{*}$ is significant, GDP has a different impact when the regime is fully democratic in the previous period, as opposed to the other two alternatives. Consequently, if both $G D P * Y_{0}^{*}$ and $G D P * Y_{1}^{*}$ are significant, GDP has a different effect for all three lagged regime types.

The results of this analysis are illustrated in Table 7 in raw form, showing the significance of the direct and interactive effects, and in Table 8 in a more easily interpretable 


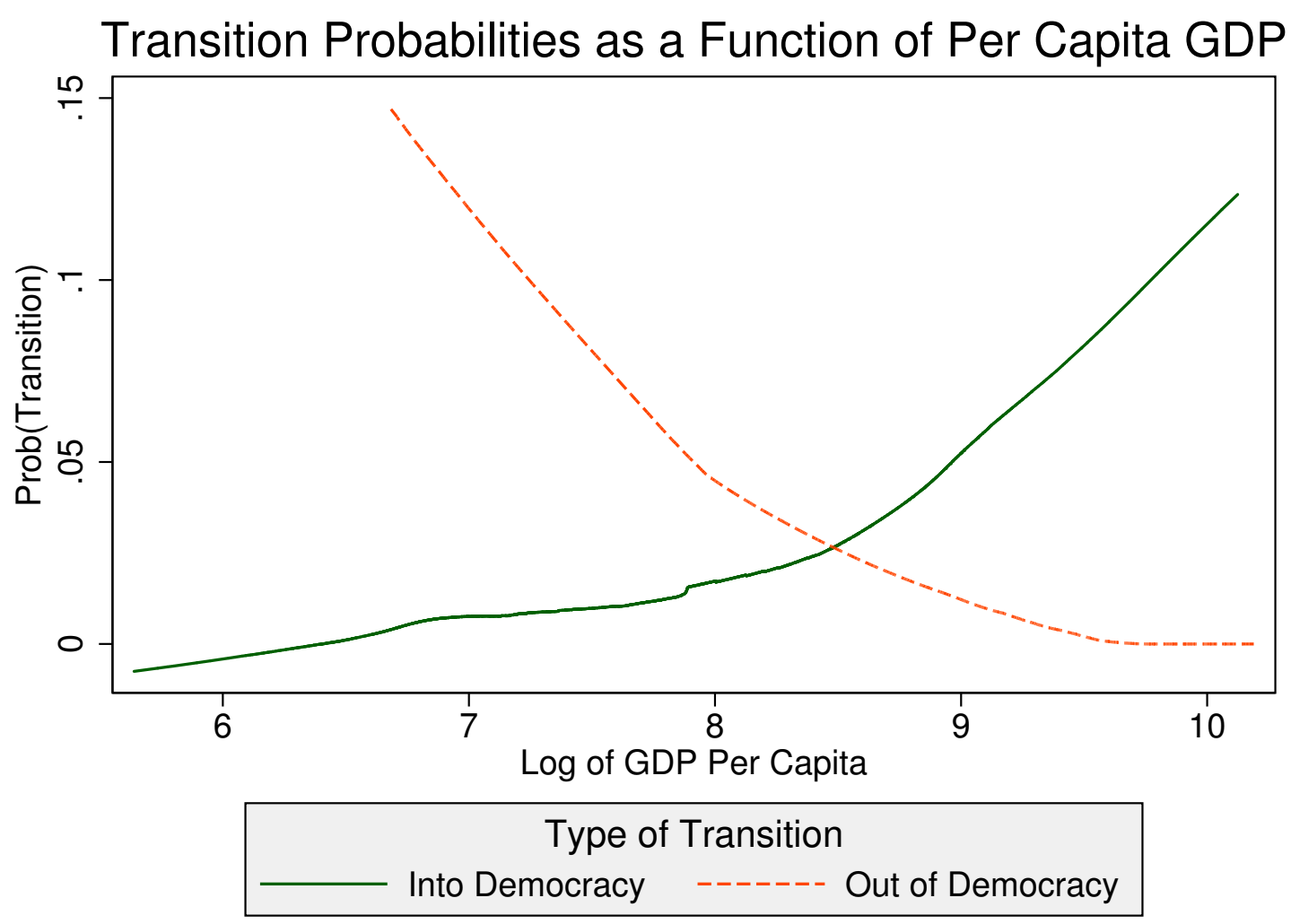

Figure 3: Impact of GDP on Transition Probabilities

format. Beginning with the former, we see that the significance levels of the coefficients on the modernization variables are similar in all three models. In particular, GDP per capital is highly significant in all specifications.

Table 8 distills the results from the analysis, showing only the relevant (sums of) coefficients from the direct and interactive effects. Coefficients that straddle table rows have similar effects for the adjacent categories. In all three models, for example, GDP has a similar impact on democratization when the country in question was autocratic or partially democratic in the previous period, as opposed to fully democratic. If the country was autocratic or partially democratic, the coefficient is 0.18 (the sum of GDP and $G D P * Y_{1}^{*}$ in Table 7 ); if the country was fully democratic, then the coefficient on GDP in Model 1 is 0.80 (the direct effect from Table 7). Both are significant, as they are in Models 2 and 3 as well, indicating that higher GDP does produce more democratic regimes, no matter what the starting point, and no matter which sets of covariates are added to the estimation equation.

The other findings in the table are also interesting, and help shed light on the results from the Tobit analysis above. The coefficient on growth, for example, is significant only for countries starting as autocracies, in which case it inhibits democratic transitions; otherwise, growth is not a significant factor. This result explains the negative coefficient on growth 
Table 7: Markov regression analysis

\begin{tabular}{|c|c|c|c|}
\hline & \multicolumn{3}{|c|}{ Model } \\
\hline & (1) & $(2)$ & $(3)$ \\
\hline Lagged $Y_{0}$ & $\begin{array}{l}-2.686 \\
(.073)^{* * *}\end{array}$ & $\begin{array}{l}-2.979 \\
(.758)^{* * *}\end{array}$ & $\begin{array}{l}-2.866 \\
(.105)^{* * *}\end{array}$ \\
\hline Lagged $Y_{1}$ & $\begin{array}{c}2.226 \\
(.85)^{* * *}\end{array}$ & $\begin{array}{c}4.134 \\
(1.491)^{* * *}\end{array}$ & $\begin{array}{c}3.836 \\
(1.538)^{* *}\end{array}$ \\
\hline GDP Per Capita & $\begin{array}{c}.8 \\
(.096)^{* * *}\end{array}$ & $\begin{array}{l}1.118 \\
(.202)^{* * *}\end{array}$ & $\begin{array}{c}.997 \\
(.218)^{* * *}\end{array}$ \\
\hline GDP per capita $* Y_{1}$ & $\begin{array}{c}-.622 \\
(.105)^{* * *}\end{array}$ & $\begin{array}{l}-.971 \\
(.219)^{* * *}\end{array}$ & $\begin{array}{l}-.803 \\
(.231)^{* * *}\end{array}$ \\
\hline GDP Growth & & $\begin{array}{r}-.127 \\
(.973)\end{array}$ & $\begin{array}{l}-.385 \\
(.986)\end{array}$ \\
\hline GDP Growth $* Y_{0}$ & & $\begin{array}{l}-2.232 \\
(1.302)^{*}\end{array}$ & $\begin{array}{c}-1.844 \\
(1.305)\end{array}$ \\
\hline Pct. Urban Pop. & & $\begin{array}{l}-.016 \\
(.007)^{* *}\end{array}$ & $\begin{array}{r}-.012 \\
(.008)\end{array}$ \\
\hline Pct. Urban Pop. ${ }^{*} Y_{1}$ & & $\begin{array}{l}.019 \\
(.008)^{* *}\end{array}$ & $\begin{array}{l}.013 \\
(.008)\end{array}$ \\
\hline Population Density & & $\begin{array}{l}.017 \\
(.034)\end{array}$ & \\
\hline Population Density ${ }^{*} Y_{0}$ & & $\begin{array}{l}.075 \\
(.049)\end{array}$ & \\
\hline Trade Openness & & & $\begin{array}{c}.228 \\
(.129)^{*}\end{array}$ \\
\hline Trade Openness ${ }^{*} Y_{1}$ & & & $\begin{array}{l}-.236 \\
(.142)^{*}\end{array}$ \\
\hline Previous Transitions & & & $\begin{array}{l}-.023 \\
(.013)^{*}\end{array}$ \\
\hline Previous Transitions $* Y_{0}$ & & & $\begin{array}{c}.033 \\
(.009)^{* * *}\end{array}$ \\
\hline Previous Transitions ${ }^{*} Y_{1}$ & & & $\begin{array}{l}.026 \\
(.015)^{*}\end{array}$ \\
\hline Resource Curse & & & $\begin{array}{l}-.185 \\
(.098)^{*}\end{array}$ \\
\hline $\mathrm{N}$ & 4299 & 3789 & 3789 \\
\hline Pseudo- $R^{2}$ & .773 & .776 & .780 \\
\hline
\end{tabular}

Note: All independent variables lagged one year. ${ }^{*}=.10 ; * *=.05 ; * * *=.01$. 
Table 8: Summary of Markov Results

\begin{tabular}{|c|c|c|c|c|}
\hline & & \multicolumn{3}{|c|}{ Model } \\
\hline & & (1) & $(2)$ & $(3)$ \\
\hline \multirow[t]{2}{*}{ GDP Per Capita } & $\begin{array}{l}\mathrm{A} \\
\mathrm{P}\end{array}$ & $0.18^{* * *}$ & $0.15^{* *}$ & $0.19^{* *}$ \\
\hline & $\mathrm{D}$ & $0.80^{* * *}$ & $1.04^{* * *}$ & $1.00^{* * *}$ \\
\hline \multirow[b]{2}{*}{ GDP Growth } & $\mathrm{A}$ & & $-2.34^{* * *}$ & $-2.23^{* *}$ \\
\hline & $\begin{array}{l}\mathrm{P} \\
\mathrm{D}\end{array}$ & & -0.189 & -0.386 \\
\hline \multirow[t]{2}{*}{ Percent Urban Pop. } & $\begin{array}{l}\mathrm{A} \\
\mathrm{P}\end{array}$ & & 0.002 & -0.0001 \\
\hline & $\mathrm{D}$ & & $-0.015^{* *}$ & $-0.013^{*}$ \\
\hline \multirow[b]{2}{*}{ Population Density } & $\mathrm{A}$ & & $0.095^{* * *}$ & \\
\hline & $\begin{array}{l}\mathrm{P} \\
\mathrm{D}\end{array}$ & & 0.021 & \\
\hline \multirow[t]{2}{*}{ Trade Openness } & $\begin{array}{l}\mathrm{A} \\
\mathrm{P}\end{array}$ & & & -0.010 \\
\hline & $\mathrm{D}$ & & & $0.227^{*}$ \\
\hline \multirow{3}{*}{ Previous Transitions } & $\mathrm{A}$ & & & $0.035^{* * *}$ \\
\hline & $\mathrm{P}$ & & & 0.002 \\
\hline & $\mathrm{D}$ & & & $-0.024^{*}$ \\
\hline Resource Curse & $\begin{array}{l}\mathrm{A} \\
\mathrm{P} \\
\mathrm{D}\end{array}$ & & & $-0.186^{*}$ \\
\hline
\end{tabular}

Note: Coefficients refer to the relevant sums of direct and interactive effects. $*<0.10$; $* *<0.05 ; * * *<0.01$. A = Autocracy; $\mathrm{P}=$ Partial Democracy; $\mathrm{D}=$ Full Democracy. 


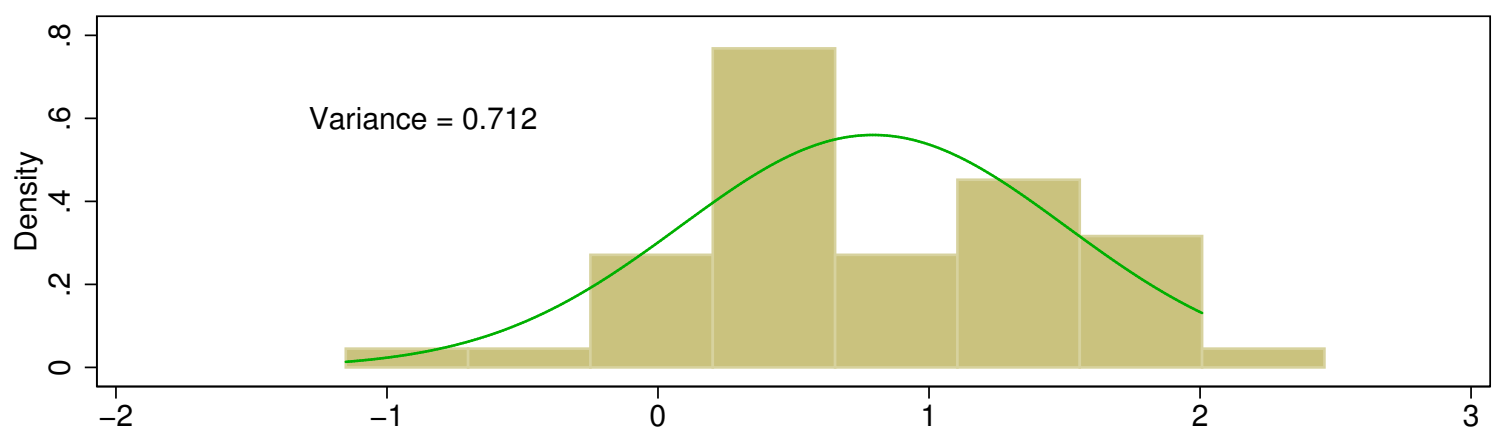

(a) Log of GDP/capita for Transitions to Democracy

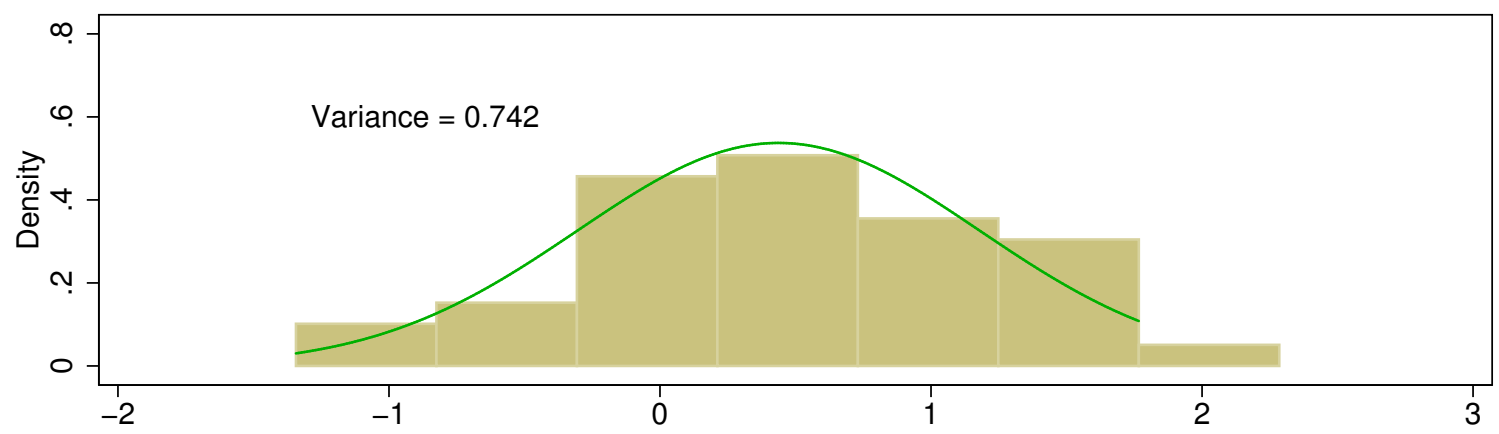

(b) Log of GDP/capita for Transitions to Autocracy

Figure 4: Distribution of GDP for Transitions To and From Democracy

in Table 6. Urbanization, on the other hand, appears to undermine democracies but has no effect on other regime categories. And population density, significant in Model 2 only, promotes transitions out of autocracy but has no impact on partially or fully democratic regimes.

Turning to the political variables, trade openness helps stabilize full democracies, but it does not help autocratic or partially democratic regimes move up the ladder. The results for our PrevTrans variable illustrate the power of the Markov approach. Previous transitions destabilize autocracies, have no impact on partial democracies, and make full democracies more likely to backslide; in other words, they are a destabilizing force. Thus a single variable can have different impacts (in fact, opposite signs) depending on the starting point in the previous period. Finally, the resource curse tends to make all regime categories more autocratic.

Why do our results from the Markov analysis vary so markedly from PACL's? They, after all, test a similar model to ours. Perhaps the difference comes from our coding of the dependent variable: we use Polity scores, while PACL employ their own measure of autocracy and democracy. If we substitute our Polity measure into their regressions, though, combining partial and full democracies into a single democratic category, the estimation results from PACL's model specification still hold. In particular, even with a Polity version of the dependent variable, lagged GDP is shown to be a significant predictor of transitions out of democracy, but not to democracy.

Conversely, we dropped the "partial" category in our data set. With this specification, 
the coefficient on GDP is, as PACL concluded, significant for transitions to autocracy, but not to democracy. In both data sets, then, one can reproduce PACL's results using a dichotomous regime classification with Polity data, and thus rule out the possibility that differences in the measure of democracy account for differences in our findings.

Continuing in this fashion, we subdivide the two PACL regime categories into four: 1) PACL autocracies that we did not list as partial democracies; 2) PACL autocracies that we list as partial democracies; 3) PACL democracies that we list as partial democracies; and 4) PACL democracies that we did not list as partial democracies. PACL combine categories 1 and 2 versus 3 and 4, while we combine 2 and 3 together, but leave 1 and 4 as distinct categories. If our categorization is correct, then we should see relatively more transitions out of category 1 into categories 2,3 , or 4 than we would see from categories 1 and 2 to categories 3 or 4 . And, in fact, $2.63 \%$ of regimes transition out of category 1 , which is a $49 \%$ increase over the $1.76 \%$ that transition out of categories 1 or 2 .

Moreover, when we run a Markov regression with GDP as an independent variable, we find that the coefficients separating categories 2 and 3 are uniformly insignificant, while those separating category 1 from category 2 and category 3 from category 4 are uniformly significant. This finding supports the use of our tripartite regime classification rather than PACL's dichotomous specification.

Finally, note the elusive nature of partial democracies. Although we can gain some understanding of the factors that make autocracies (or full democracies) become partially democratic, we have little information as to the factors that would lead partial democracies to either slide down to autocracy or to move up to full democracy. In fact, examining the saturated regression with all direct and interactive effects, we find that none of the coefficients on partial democracy are significant on their own. Numerous, volatile, and shaping the dynamics of regime transitions, the determinants of the behavior of the partial democracies elude our understanding.

\section{Duration Analysis}

We now turn to the duration analysis, which highlights the factors that help countries stay democratic. Given our trichotomous measure of democracy, there are two ways in which we could approach this issue: what prevents full democracies from sliding back to partial democracies or autocracies, and what prevents partial democracies from sliding back to autocracy?

PACL also perform duration analysis, and they argue that new democracies are in fact more likely to fail than more established ones, but that once GDP per capita is taken into account, this difference disappears. We examine this conclusion using the same three models as in the previous section.

Table 9 shows the results of estimating the probabilities that states fall out of full democracy. The frailty terms were significant in all specifications, and so they are retained in the estimation equations.

Note first that in all specifications, higher GDP per capita reduces the probability that countries fall out of democracy. Other than this finding, however, the results offer few clues as to the factors that help prevent backsliding. Higher urban populations are a risk factor for democracies in Model 2, and trade openness is a stabilizing factor in Model 3, 
Table 9: Survival analysis of transitions out of full democracy

\begin{tabular}{lccc}
\hline & \multicolumn{3}{c}{ Model } \\
\cline { 2 - 4 } & $(1)$ & $(2)$ & $(3)$ \\
\hline GDP Per Capita & -1.853 & -2.784 & -2.895 \\
GDP Growth & $(.328)^{* * *}$ & $(.65)^{* * *}$ & $(.777)^{* * *}$ \\
& & -6.8 & -6.526 \\
Pct. Urban Pop. & & $(7.136)$ & $(7.785)$ \\
& & .041 & .031 \\
Population Density & & $.022)^{*}$ & $(.026)$ \\
& & $(.236)$ & .023 \\
Trade Openness & & & -1.265 \\
& & & $(.505)^{* *}$ \\
Previous Transitions & & & .067 \\
& & & $(.04)^{*}$ \\
Resource Curse & & & .448 \\
& & & $(.855)$ \\
N & 1483 & 1356 & 1356 \\
Log Likelihood & -78.326 & -63.167 & -58.778 \\
$\theta$ & .383 & .67 & .895 \\
\hline
\end{tabular}

Note: All independent variables lagged one year. ${ }^{*}=.10 ; * *=.05 ; * * *=.01$.

but no other coefficients are significant.

Figure 5 graphs the impact of GDP on transitions, plotting the smoothed hazard rates both with and without adjustment for GDP per capita. ${ }^{19}$ The top figure shows that the risk of falling out of democracy rises at first, then declines after the first seven years as a full democracy. The bottom figure tells a very different story. Here, after adjusting for GDP per capita, the risk of failure rises steadily for about twenty years, and then plateaus. To put it another way, it is the average increase in per capita GDP that causes the reduction in the hazard rate in the top figure. The key to consolidation of new democracies, it would appear, is a strong economy.

We now repeat the above analysis for partial democracies, to see if similar factors keep semi-democratic societies from falling back into autocracy. ${ }^{20}$ Here, the frailty terms were never significant and were dropped from the estimation.

Table 10 presents the results. Compared with transitions from full democracy, the predictive ability of these models is much smaller. The coefficient on GDP per capita is

\footnotetext{
${ }^{19}$ The adjustment sets GDP per capita at its mean value and calculates hazard rates for all other variables. The fact that the curve flattens out is evidence that variation in GDP accounts for the U-shaped function in the top figure.

${ }^{20}$ Since we are interested in the question of stabilizing partial democracies, transitions to full democracy are treated as censored observations in this part of the analysis.
} 

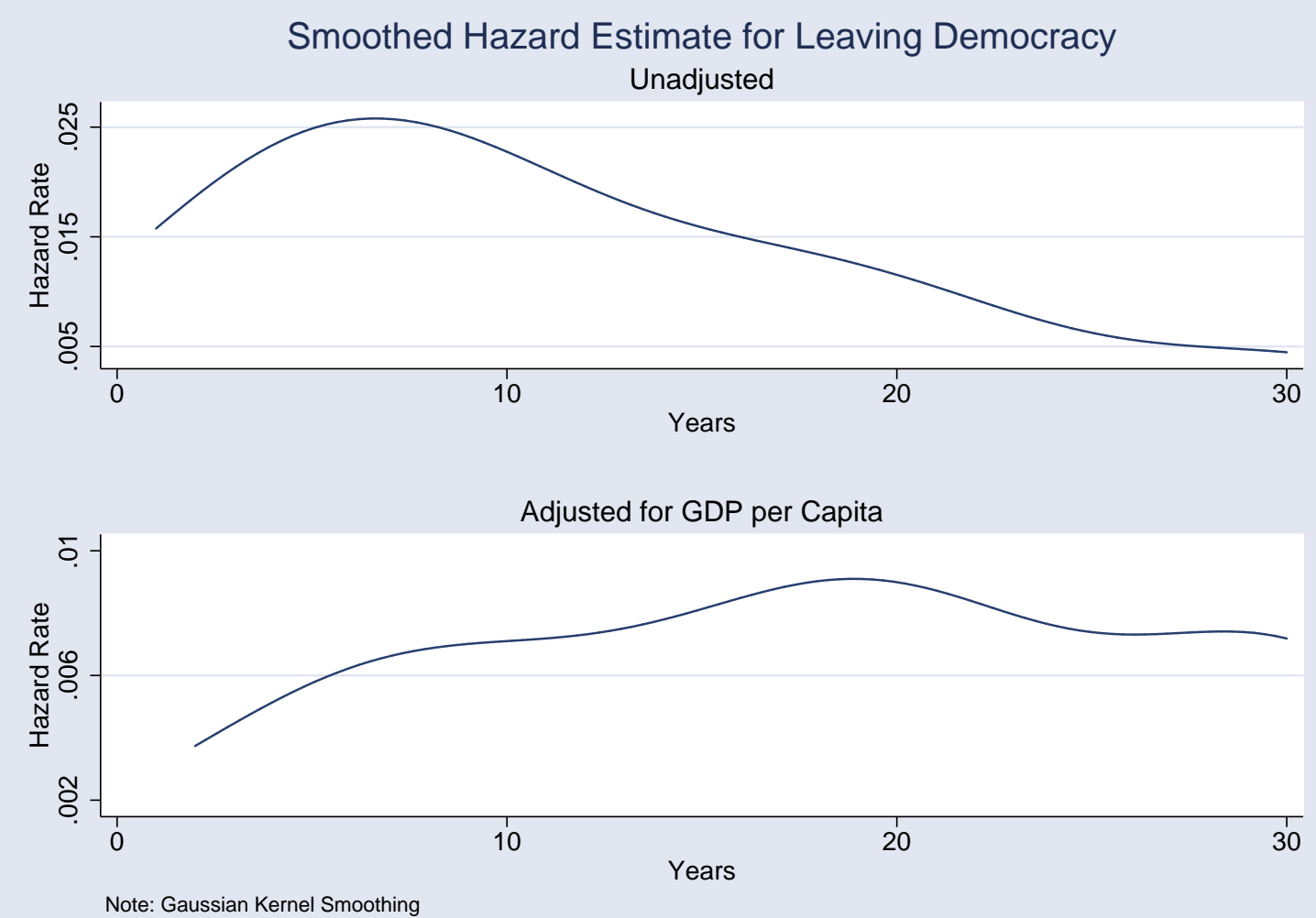

Figure 5: Adjusted and Unadjusted Hazard Rates for Falling Out of Democracy

again negative in all specifications, but marginally significant in Model 2 and insignificant in Model 3. The only other significant variables are trade openness and the resource curse in Model 3, the former associated with less risk of falling into autocracy, the latter with increased risk. ${ }^{21}$ And the log likelihoods of all models are smaller than those in Table 9.

Neither does Figure 6 offer much evidence as to the factors that affect the consolidation of partial democracies. The unadjusted hazard rate in the top half of the figure rises gently, turning negative only after 13 years (at which point there are relatively few data points remaining in the sample). This general pattern does not change, even after adjusting not just for GDP, but for all independent variables in Model 3. As in the Markov analysis, then, the factors affecting transitions out of partial democracy remain poorly understood.

\section{Conclusion}

This paper has returned to the analysis of the relationship between modernization and democracy. In doing so, it has reappraised the central argument of the works of PACL,

\footnotetext{
${ }^{21}$ One might also reasonably inquire whether countries becoming partial democracies after falling out of full democracy show different patterns in their hazard rates. To evaluate this possibility, a variable FullToPart was added to the analysis, but it was never significant.
} 
Table 10: Survival analysis of transitions from partial democracy to autocracy

\begin{tabular}{lccc}
\hline & \multicolumn{3}{c}{ Model } \\
\cline { 2 - 4 } & $(1)$ & $(2)$ & $(3)$ \\
\hline GDP Per Capita & -.695 & -.692 & -.603 \\
& $(.221)^{* * *}$ & $(.356)^{*}$ & $(.395)$ \\
GDP Growth & & 3.939 & 4.295 \\
& & $(3.651)$ & $(3.799)$ \\
Pct. Urban Pop. & & -.002 & -.006 \\
& & $.014)$ & $(.017)$ \\
Population Density & & .008 & .034 \\
& & $(.131)$ & $(.166)$ \\
Trade Openness & & & -.882 \\
& & & $(.351)^{* *}$ \\
Previous Transitions & & & -.006 \\
& & & $(.026)$ \\
Resource Curse & & & .903 \\
& & & $(.513)^{*}$ \\
Obs. & 703 & 627 & 627 \\
e(ll) & -153.779 & -131.85 & -128.113 \\
\hline
\end{tabular}

Note: All independent variables lagged one year. ${ }^{*}=.10 ;{ }^{*}=.05 ; * * *=.01$.

the standard against which all other work in this field should be measured.

We find that PACL themselves erred in their own analysis, failing to correctly estimate the standard errors of the coefficients reported in their Markov models; and that when doing so, the erred in a way that led them to report the impact of GDP on democratization as insignificant. As did PACL, we too employed Markov methods; and when we did so, we found reason to prefer a three-category classification of democratic regimes to the dichotomous categorization that they employed. Classifying countries into autocracies, democracies, and partial democracies, we demonstrated that higher incomes per capita significantly increased the likelihood of democratic regimes, both by enhancing the consolidation of existing democracies and by promoting transitions from authoritarian to democratic systems.

Our trichotomous measure proved valuable for an additional reason: it highlighted the significance of the middle category - the partial democracies - a category whose properties and significance were necessarily obscured in the PACL analysis. These are "fragile" democracies, or perhaps "unconsolidated democracies." Whatever one wishes to call them, they emerge from our analysis as critical to the understanding of democratic transitions. More volatile than either straight autocracies or democracies, their movements seem at the moment to be largely unpredictable. One of our major conclusions, then, is that it is this category - the partial democracies - upon which future research should focus. 

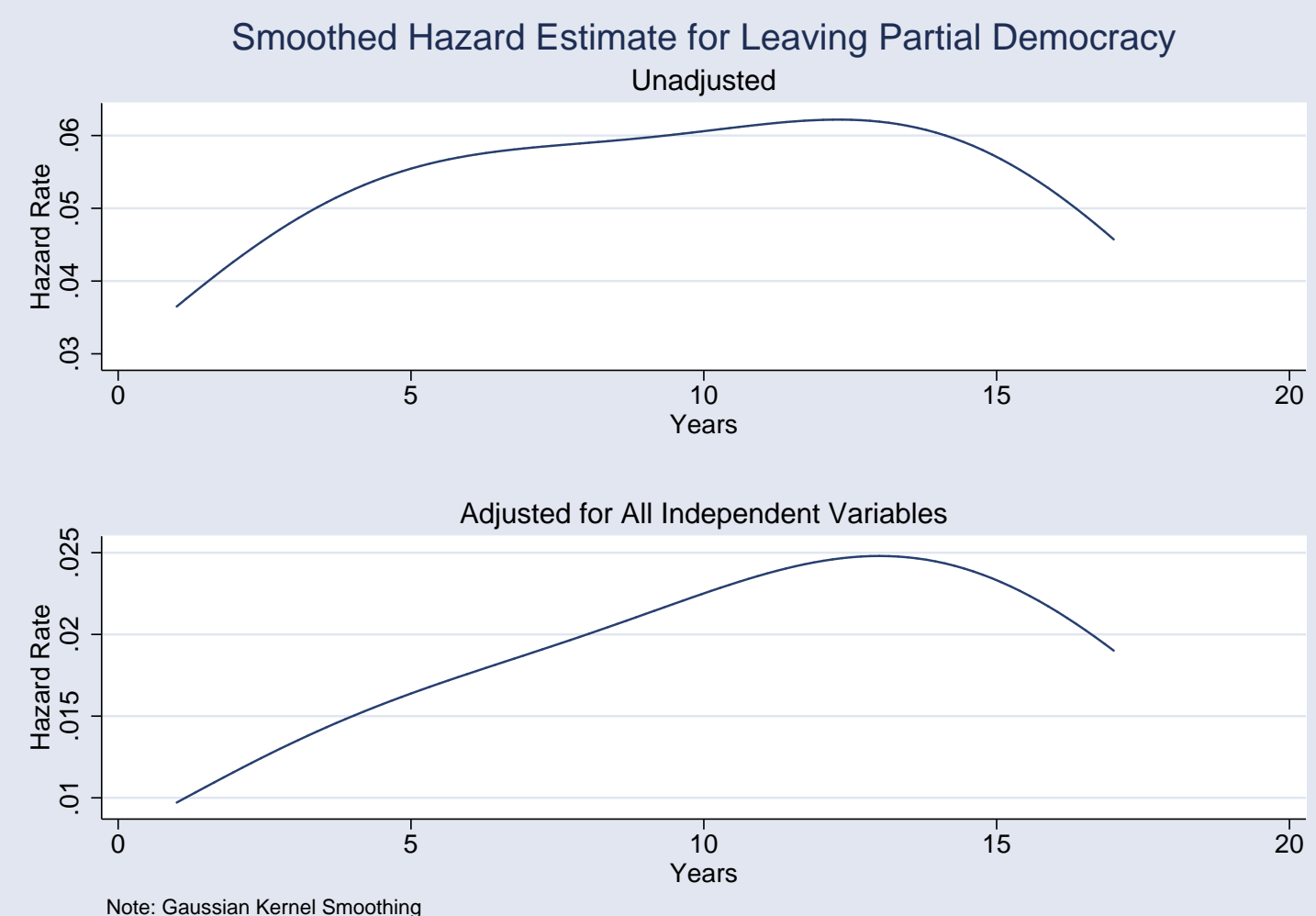

Figure 6: Adjusted and Unadjusted Hazard Rates for Transitions from Partial Democracy to Autocracy

We also note that this is one area of scholarly inquiry with important implications for policy. In the present era, countries are reforming both politically and economically. Politically, they seek democracy. Economically, they pursue policies to promote economic growth. Should these reforms be sequential or simultaneous; and if sequential, which - the political or the economic - should come first? PACL's (2000) conclusion that economic growth does not aid democratization, while democratic political institutions foster growth, puts them squarely in the "politics first" camp.

In arguing with PACL's conclusions, though, we do not mean to imply that economic reforms should take primacy over the political, as the problems of untangling the issues of reciprocal causality in this field are intense. Indeed, the current literature on policy reform deals with exactly these causality issues by trying to find a suitable instrument for institutions, broadly defined, that is not in turn affected by the level of economic development. Rodrik, Subramanian and Trebbi (2004), for instance, use the widelyknown Acemoglu, Johnson and Robinson (2001) measure of settler mortality as a proxy for institutional quality. They find that institutions are far more important as determinants of economic growth than are either geography or trade. Glaeser, La Porta, Lopez-de-Silanes, and Shleifer (2004) disagree with this conclusion, claiming that in fact better property rights 
under dictatorships help spur economic growth, which in turn facilitates the emergence of democratic governance.

To this fruitful, ongoing debate we add a reminder that leaving autocracy is not the same as entering democracy. Between these two lie partial democracies, which often act in a manner distinct from those countries either more or less democratic than they, and whose dynamics, while shaping contemporary politics, remain poorly understood. 


\section{References}

[1] Acemoglu, Daron, Simon Johnson and James Robinson. 2001. "The Colonial Origins of Comparative Development: An Empirical Investigation." American Economic Review 91: 1369-1401.

[2] Acemoglu, Daron and James Robinson. 2001. "A Theory of Political Transitions." American Economic Review 91:938-963.

[3] Bacher, John. 1998. "Oil and Dictatorship." Peace Magazine 14: 8.

[4] Boix, Carles. 2002. Democracy and Redistribution. New York: Cambridge University Press.

[5] Boix, Carles and Susan Stokes. 2003. "Endogenous Democratization." World Politics 55: $517-549$.

[6] Bollen, K. and Robert Jackman. 1989. "Democracy, Stability, and Dichotomies." American Sociological Review 54: 612-21.

[7] Box-Steffensmeier, Jan, and Christopher Zorn. 2002. "Duration Models for Repeated Events." Journal of Politics 64:1069-94.

[8] Burkhart, Ross E. and Michael S. Lewis-Beck. 1994. "The Economic Development Thesis." American Political Science Review 88: 903-10.

[9] Chenery, Hollis B. and Lance J. Taylor. 1968. "Development Patterns: Among Countries and Over Time." Review of Economics and Statistics 50: 391-416.

[10] Clayton, David G. 1992. "Repeated Ordinal Measurements: A Generalised Estimating Equation Approach." Medical Research Council Biostatistics Unit Technical Report. Cambridge, England.

[11] Collier, David and Robert Adcock. 1999. "Democracy and Dichotomies: A Pragmatic Approach to Choices about Concepts. Annual review of Political Science." In Nelson Polsby, ed. Annual Review of Political Science. Palo Alto: Stanford University Press.

[12] Collier, David and Steven Levitsky. 1997. "Democracy with Adjectives: Conceptual Innovation in Comparative Research." World Politics 49: 430-51.

[13] Cutright, Phillips. 1963. "National Political Development: Social and Economic Correlates." In Polsby, Nelson W., Robert A. Dentler and Paul A. Smith, eds., Politics and Social Life: An Introduction to Political Behavior. Boston: Houghton Mifflin.

[14] Dahl, Robert A. 1971. Polyarchy: Participation and Opposition. New Haven: Yale University Press.

[15] Deutsch, Karl W. 1961. "Social Mobilization and Political Development." American Political Science Review 55(3): 493-510. 
[16] Diggle, Peter, Kung-Yee Liang and Scott Zeger. 2002. Analysis of Longitudinal Data. Oxford: Oxford University Press.

[17] Elkins, Zachary. 2000. "Gradations of democracy? Empirical tests of alternative conceptualizations." American Journal Political Science 44(2): 293-300.

[18] Goldstone, Jack, Robert Bates, David Epstein, et al. 2000. State Failure Task Force: Phase III Findings. McLean, VA: SAIC.

[19] Goldstone, Jack A. and Adriana Kocornik-Mina. 2005. "Democracy and Development: New Insights from Dynagraphs." George Mason University, Center for Global Policy, Working Paper \#1. Fairfax, VA.

[20] Geddes, Barbara 1999. "What Do We Know About Democratization After Twenty Years?" Annual Review of Political Science 2: 115-44.

[21] Glaeser, Edward, Rafael La Porta, Florencio Lopez-de-Silanes, and Andrei Shleifer. 2004. "Do Institutions Cause Growth?" Journal of Economic Growth 9: 271-303.

[22] Greene, William. 2003. Econometric Analysis. Upper Saddle River, NJ: Prentice Hall.

[23] Jaggers, Keith and Ted R. Gurr. 1995. "Tracing Democracy's Third Wave with the Polity III Data." Journal of Peace Research 31(4): 469-82.

[24] Kuznets, Simon. 1966. Modern Economic Growth: Rate, Structure, and Spread. New Haven: Yale University Press.

[25] Lancaster, Tony. 1990. The Econometric Analysis of Transition Data. New York: Cambridge University Press.

[26] Lerner, Daniel 1958. The Passing of Traditional Society. New York: Free Press of Glencoe.

[27] Lipset, Seymour Martin 1959. "Some Social Requisites of Democracy." American Political Science Review 53: 69-105.

[28] Londregan, John B. and Keith T. Poole. 1996. "Does High Income Promote Democracy?" World Politics 49: 1-30.

[29] Mansfield, Edward and Jack Snyder. 1995. "Democratization and War." Foreign Affairs 74:79-97.

[30] Manton, Kenneth G., Eric Stallard and James W. Vaupel. 1981. "Methods for Comparing the Mortality Experience of Heterogeneous Populations." Demography 18(August):389-410.

[31] Moore, Barrington. 1966. Social Origins of Dictatorship and Democracy. Boston: Beacon Press.

[32] Munck, Gerardo L. and Jay Verkuilen. 2002. "Conceptualizing and Measuring Democracy: Evaluating Alternative Indices." Comparative Political Studies 35: 5-34. 
[33] Omori, Yasuhiro and Richard A. Johnson. 1993. "The Influence of Random Effects on the Unconditional Hazard Rate and Survival Functions." Biometrika 80(4):910- 14.

[34] Przeworski, Adam, Michael E. Alvarez, Jose Cheibub and Fernando Limongi. 1996. "What Makes Democracies Endure?" Journal of Democracy 7: 3-36.

[35] Przeworski, Adam and Fernando Limongi. 1997. "Modernization: Theories and Facts." World Politics 49: 155-83.

[36] Przeworski, Adam, Michael E. Alvarez, Jose Cheibub and Fernando Limongi. 2000. Democracy and Development. New York: Cambridge University Press.

[37] Rodrik, Dani. 1997. Has Globalization Gone Too Far? Washington D.C.: Institute for International Economics.

[38] Rueschemeyer, Dietrich, Evelyne Huber Stephens, and John D. Stephens. 1992. Capitalist Development and Democracy. Chicago: University of Chicago Press.

[39] Rodrik, Dani, Arvind Subramanian and Francesco Trebbi. 2004. "Institutions Rule: The Primacy of Institutions over Geography and Integration in Economic Development." Journal of Economic Growth 9: 131-65.

[40] Ross, Michael L. 1999. "The Political Economy of the Resouce Curse." World Politics 51: $325-61$.

[41] Rostow, Walt Whitman. 1960 The Stages of Economic Growth. Cambridge: Cambridge University Press.

[42] Vaupel, James W., Kenneth G. Manton, and Eric Stallard. 1979. "The Impact of Heterogeneity in Individual Frailty on the Dynamics of Mortality." Demography 16:439-54.

[43] Zakaria, Fareed. 2003. The Future of Freedom. New York: W. W. Norton. 


\section{Appendix 1: Descriptive Statistics on Transitions}

We have 169 countries in the dataset. ${ }^{22}$. Their patterns of stability and transitions are as follows:

- 41 very stable countries: same Polity value throughout the dataset

- 23 very stable full democracies with Polity value of $10^{23}$

- 1 very stable democracy with Polity value of $8^{24}$

-4 very stable partial democracies existing between 8 and 11 years $^{25}$

-13 very stable autocracies ${ }^{26}$

- 42 stable countries: same category (autocracy, partial or democracy) throughout the dataset but Polity value changes

-4 stable democracies ${ }^{27}$

- 4 stable partial democracies ${ }^{28}$ (Note: none of these countries is more than 10 years old.)

- 34 stable autocracies ${ }^{29}$

After identifying the very stable and the stable countries, we want to characterize the countries making transitions between categories. Two features seem to be of interest: how many categories the country visited during our time period, and the direction of the changes. Concerning the latter feature, we distinguish between somewhat stable countries making a single transition during the time period studies and unstable countries making several transitions.

\footnotetext{
${ }^{22}$ Twenty-five countries that existed during our sample period had no Polity scores: Andorra, Antigua \& Barbuda, Bahamas, Barbados, Belize, Bosnia and Herzegovina, Brunei, Cape Verde, Dominica, Grenada, Liechtenstein, Maldive Islands, Malta, Monaco, Palau, San Marino, Sao Tome-Principe, Seychelles, Solomon Islands, St. Kitts-Nevis, St. Lucia, St. Vincent and the Grenadines, Suriname, Vanuatu, and Western Samoa.

${ }^{23}$ Countries existing in all 41 years are: Australia, Austria, Belgium, Canada, Costa Rica, Denmark, Finland, Iceland, Ireland, Italy, Japan, Netherlands, New Zealand, Norway, Sweden, Switzerland, and UK. Countries existing less than all 41 years are: Czech Republic (8), Germany (11), West Germany (30), Lithuania (10), Papua New Guinea (26), and Slovenia (10).

${ }^{24}$ Latvia (10)

${ }^{25}$ Estonia (10), Ethiopia after 1993 (8), Macedonia (10), Namibia (11)

${ }^{26}$ Countries existing in all 41 years are: Bhutan, Cuba, Libya, and Saudi Arabia. Countries existing less than all 46 years are: Eritrea (8), East Germany (29), Kyrgyzstan (10), Qatar (30), United Arab Emirates (30), Uzbekistan (10), Vietnam (25), South Vietnam (16), and Yemen (11).

${ }^{27}$ Israel, Jamaica, Mauritius, and Trinidad.

28 Georgia, Moldova, Russia, and Ukraine

${ }^{29}$ Afghanistan, Algeria, Angola, Bahrain, Burundi, Cameroon, Chad, China, Congo-Kinshasa, Egypt, Gabon, East Germany, Guinea, Iraq, Jordan, Kazakhstan, North Korea, Kuwait, Laos, Liberia, Mauritania, Morocco, Oman, Rwanda, Swaziland, Syria, Tajikistan, Togo, Tunisia, Turkmenistan, USSR, North Vietnam, North Yemen, South Yemen, and Former Yugoslavia.
} 
- 56 shifting between two categories

- 9 shifting between partial and democracy

* 4 somewhat stable: 3 countries up to democracy ${ }^{30}$ and 1 down to partial ${ }^{31}$

* 4 unstable countries going up once and down once ${ }^{32}$

- 37 shifting between partial and autocracy

* 22 somewhat stable: 15 up to partial ${ }^{33}$ and 7 down to autocracy ${ }^{34}$

* 17 unstable $^{35}$

- 11 shifting between autocracy and democracy

* 9 somewhat stable: 7 countries up to democracy ${ }^{36}$ and 2 down to autocracy $^{37}$

* 2 unstable countries going two categories up once and two down once ${ }^{38}$

- 30 shifting between all three categories

- Only in one direction

* 6 countries up ${ }^{39}$ and none the other way

-24 back and forth

* 12 countries making 3 transitions between categories ${ }^{40}$

* 4 making 4 transitions ${ }^{41}$

* 4 making 5 transitions ${ }^{42}$

* 2 making 6 transitions ${ }^{43}$

* 1 making 7 transitions ${ }^{44}$

${ }^{30}$ Botswana, France, Slovakia, and South Africa

31 Malaysia

32 Columbia, France, India, and Sri Lanka

33 Central African Republic, Cote d'Ivoire, Croatia, Djibouti, El Salvador, Guinea-Bissau, Honduras, Indonesia, Iran, Malawi, Mali, Mozambique, Paraguay, Tanzania, and Yugoslavia

34 Belarus, Equatorial Guinea, Kenya, Singapore, Somalia, Syria, and Zimbabwe

35 Up once and down once: Armenia, Azerbaijan, Benin, Burkina Faso, Guyana, Pakistan (pre-1972), and Zambia. More shifts: Albania, Cambodia, Comoros, Congo-Brazzaville, Ghana, Haiti, Nepal, Sierra Leone, and Uganda

${ }^{36}$ Bolivia, Bulgaria, Czechoslovakia, Hungary, Portugal, Senegal, and Spain

37 Burma and Laos

38 Lesotho and Uruguay

39 Mexico, Mongolia, Nicaragua, Poland, Romania, and Taiwan

40 Bangladesh, Brazil, Chile, Colombia, Fiji, Gambia, Greece, Madagascar, Niger, Panama, Philippines, and Venezuela

${ }^{41}$ Dominican Republic, Guatemala, Pakistan (post-1972), and Sudan

42 Argentina, Ecuador, Nigeria, and South Korea

43 Peru and Turkey

44 Thailand 


\section{Appendix 2: Countries in Each Region}

Africa: Angola, Benin, Botswana, Burkina Faso, Burundi, Cameroon, Central African Republic, Chad, Comoros, Congo-Brazzaville, Congo-Kinshasa, Cote d'Ivoire, Djibouti, Equatorial Guinea, Eritrea, Ethiopia, Gabon, The Gambia, Ghana, Guinea, GuineaBissau, Kenya, Lesotho, Liberia, Madagascar, Malawi, Mali, Mauritania, Mauritius, Mozambique, Namibia, Niger, Nigeria, Rwanda, Senegal, Sierra Leone, Somalia, South Africa, Sudan, Swaziland, Tanzania, Togo, Uganda, Zambia, Zimbabwe

East Asia: Australia, Burma, China, Fiji, Indonesia, Japan, North Korea, South Korea, Laos, Malaysia, Mongolia, New Zealand, Papua New Guinea, Philippines, Singapore, Solomon Islands, Taiwan, Thailand, Vietnam

Europe: Albania, Austria, Belgium, Bulgaria, Croatia, Cyprus, Czech Republic, Czechoslovakia, Denmark, Finland, France, Germany, Greece, Hungary, Iceland, Ireland, Italy, Macedonia, Netherlands, Norway, Poland, Portugal, Romania, Slovakia, Slovenia, Spain, Sweden, Switzerland, Turkey, United Kingdom, Yugoslavia

Former Soviet Union: Armenia, Azerbaijan, Belarus, Estonia, Georgia, Kazakhstan, Kyrgyzstan, Latvia, Lithuania, Moldova, Russia, Tajikistan, Turkmenistan, Ukraine, USSR(Soviet Union), Uzbekistan

Latin America: Argentina, Bolivia, Brazil, Chile, Colombia, Costa Rica, Cuba, Dominican Republic, Ecuador, El Salvador, Guatemala, Guyana, Haiti, Honduras, Jamaica, Mexico, Nicaragua, Panama, Paraguay, Peru, Trinidad, Uruguay, Venezuela

Near East: Afghanistan, Algeria, Bahrain, Bangladesh, Bhutan, Egypt, India, Iran, Iraq, Israel, Jordan, Kuwait, Lebanon, Libya, Morocco, Nepal, Oman, Pakistan, Qatar, Saudi Arabia, Sri Lanka, Syria, Tunisia, United Arab Emirates, Yemen 